\title{
Nakládání s popelem v oběhovém hospodářství obcí
}

\section{DAGMAR VOLOŠINOVÁ, VÁCLAV VACHUŠKA, ELŽBIETA ČEJKA, ROBERT KOŘÍNEK, ALEŠ VACHUŠKA, JAN VACHUŠKA}

Klíčová slova: popel - odpad - komunální odpad - nakládání s odpady - oběhové hospodářství

\section{SOUHRN}

Popel z malých tepelných zdrojů vzniká při spalování tuhých paliv, jako jsou dřevo a uhlí. Na základě průzkumu provedeného autory článku Ize popel z malých tepelných zdrojů (MTZ) považovat za největší tok odpadu v menších obcích ČR. Tento materiál má značný potenciál pro snížení produkce odpadu, skládkování a spotřeby primárních surovin. Představenými možnostmi využití tohoto potenciálu bude dodržena nejen hierarchie nakládání s odpady, ale i strategie udržitelného rozvoje mnoha obcí. Článek využívá analýzu materiálového složení směsných komunálních odpadů z dobrovolného svazku obcí Horažd’ovicko k demonstraci možného způsobu zásadní pomoci zejména malým obcím ekologicky nezávadným způsobem plnit jejich závazky vyplývající z nové odpadové legislativy.

\section{ÚVOD}

Cirkulární ekonomika kombinuje ekonomický růst s vývojovým cyklem, který zachovává a posiluje př́rodní kapitál, optimalizuje produkci zdrojů a minimalizuje rizika prostřednictvím správy omezených zdrojů a obnovitelných smyček. Kromě toho umožňuje společnostem snížit výrobní náklady a ztráty, vytváret nové zdroje přijmů a zmírnit jejich závislost na přírodních surovinách. Města a regiony jako hlavní zúčastněné strany $v$ oblastech, jako jsou stavebnictví, mobilita, potraviny, nakládání s odpady, produkty, služby a další, hrají při přechodu na oběhové hospodářství zásadní roli.

Moderní společnosti spotřebovávají mnoho surovin a produkují značné množství odpadů, především v oblasti stavebnictví. Spotřebované a vypouštěné materiály v tomto odvětví jsou zejména minerální povahy [1]

Tlak na prírodní zdroje se stále zvyšuje, přičemž je zapotřebí nová infrastruktura, služby a bydlení. Města již tvoří téměř dvě třetiny celosvětové poptávky po energii, produkují až $50 \%$ pevného odpadu a jsou zodpovědná za $70 \%$ emisí skleníkových plynů. Odhaduje se, že celosvětově se do roku 2050 množství pevného komunálního odpadu zdvojnásobí [2].

Oběhové hospodářství je založeno na třech zásadách:

\section{1. kontrolovat vznik odpadů a znečištění}

\section{2. ponechat výrobky a materiály v provozu}

3. regenerovat prírodní systémy
Oběhové hospodářství ve městech a regionech znamená systémový posun, při kterém jsou poskytovány služby, efektivně využívány přírodní zdroje primárních materiálů a optimalizováno jejich opětovné využívání. Pro dosažení ekonomické efektivity jsou činnosti plánovány a prováděny tak, aby uzavíraly, zpomalovaly a zužovaly smyčky napříč hodnotovými řetězci. Infrastruktura je navržena a vybudována tak, aby se zabránilo lineárnímu blokování, a tím plýtvání materiálem.

Očekává se, že oběhové hospodářství bude mít pozitivní dopady na životní prostředí díky snížení emisí do ovzduší, zvýšení podílu obnovitelné energie a recyklovatelných zdrojů a omezení využivání surovin, vody, půdy a energie. Stále je třeba uvolnit potenciál cirkulární ekonomiky na podporu udržitelných měst, regionů a zemí. K dosažení tohoto cíle je nutné jít nad rámec čistě technických aspektů. Vyžaduje to nastavení správného řízení a mezí prostředí. Rámec 3P („lidé" , „politiky“ a "místa”) znamená, že oběhové hospodářství zahrnuje udržitelné způsoby výroby a spotřeby, ale i nové modely podnikání a správy (lidé). Vyžaduje také holistický a systémový prístup, překračující omezení sektorové politiky, a zároveň funkční prístup, který přesáhne administrativní hranice měst a povede $k$ jejich propojení s jejich centry a venkovem, a tím k uzavření, zúžení a zpomalení cyklů ve správném měřítku (místa) [2].

Touto myšlenkou se nechal inspirovat i tým Ing. Václava Vachušky v Dobrovolném svazku obcí Horažđ’ovicko, který hledá způsoby prevence vzniku odpadů a maximalizace využití odpadů prímo na území obsluhovaných obcí. V současnosti řeší využití dvou největších toků komunálních odpadů stavebního a demoličního odpadu a popela z MTZ.

\section{POPEL Z MALÝCH TEPELNÝCH ZDROJU゚}

Vzhledem ke geografickým podmínkám ČR a rozsahu plynofikace venkova je pevné palivo jediným vstupem pro MTZ. Velkou tradici má využívání uhlí, jak černého, tak hnědého. Dalším významným palivem je dřevo štípané nebo ve formě štěpky, pelet a briket. S rostoucí cenou zemního plynu a elektřiny pak logicky dochází k opětovnému využívání uhlí, dřevěných pelet či kusového dřeva.

Výsledkem spalování je popel. Jeho množství závisí na mnoha faktorech, na druhu a kvalitě uhlí/dřeva, podmínkách hoření atd. Pro průmyslové účely obvykle slouží kotle vybavené drtiči, kde se uhlí drtí najemno, aby se optimalizovala rychlost spalování a účinnost výroby tepla. Produkty pálení uhlí v průmyslu jsou často využivány jako pomocný stavební materiál při budování silnic nebo př́pravě betonů [3]. Pro účely vytápění jednotlivých domácností se však používá mnohem výhřevnější druh uhlí, přičemž výsledný popel nemá v současnosti prakticky žádné uplatnění z důvodu nižšího produkovaného množství a potenciálně vysokých nákladů na jeho sběr. 


\title{
Výsledky analýz jednotlivých vzorků popelů [mg/kg sušiny]
}

\section{Prvek}

1

2 34

4

\section{5}

$6 \quad 7$

\section{8}

$9 \quad 10$

10

$\begin{array}{llllllllllllllllllll}\text { As } & 9,47 & 3,22 & 4,52 & 5,28 & 6,20 & 1,35 & 9,32 & 4,52 & 7,61 & 2,22 & 8,10 & 57,50 & 1,00 & 3,30 & 1,69 & 20 & 30\end{array}$

\section{$\mathrm{cd}$}

2,46

2,94

2,81

4,98

1,57

2,67

0,14

0,33

0,32

3,50

24,90

0,10

3,40

1,19

$\mathrm{Cr}$

$36,60 \quad 14,90 \quad 2,64 \quad 38,30$

18,90

29,10

24,10

26,90

$27,80 \quad 41,80$

$55,60 \quad 78,00$

11,00

40,70

$6,40 \quad 50$

100

\begin{abstract}
$\mathrm{Hg}$
\end{abstract}
0,14

0,07

$<0,05$

0,10

$<0,05 \quad 0,08$

$0,12 \quad 0$

$0,03<0,005$

0,03

1,6

0,07

0,06

0,02

0,5

0,5

\begin{tabular}{cccccccccccccccccc}
\hline $\mathrm{Pb}$ & 24,00 & 6,72 & 26,80 & 31,50 & 38,40 & 4,73 & 13,40 & 3,66 & 19,30 & 11,40 & 43,00 & 222,00 & 1,50 & 2,47 & $<2,7$ & 50 & 100 \\
\hline &
\end{tabular}

Zdroj: ARNIKA a VÚV TGM

Při zjištování bližších informací o složení pospalinových zbytků se všechny zdroje zabývaly emisemi do ovzduší, zatímco složení popelů bylo řešeno převážně jen u velkých producentů, jako jsou elektrárny a teplárny.

Popel vzniklý v MTZ spalováním čisté biomasy je prezentován jako nezávadný, vhodný pro široké využití na zahradách a v domácnostech [4-6]. Existují však názory [7, 8], podložené výsledky laboratorních analýz, že stromy mohou absorbovat a hromadit látky ze vzduchu a půdy. Proto dřevo často obsahuje znečištujující látky ve formě těžkých kovů, jejichž koncentrace se liší v závislosti na druhu stromu a lokalitě jeho růstu. Při nedokonalém spalování tak vznikají mimo jiné i organické znečištujuící látky. Tyto a všechny nehořlavé složky dřeva zůstávají po spalování koncentrovány $v$ popelu. Kromě minerálů, jako jsou draslík nebo fosfor, jsou to rovněž těžké kovy (arsen, olovo, kadmium, chrom, měd’ atd.) a různé organické znečištující látky (polycyklické aromatické uhlovodíky, dioxiny nebo furany), z nichž některé jsou toxické a/nebo karcinogenní. Použití dřevěného popela $v$ zemědělství nebo na zahradě je tedy problematické a může poškodit půdu i vodu.

Konkrétní výsledky analýz popela ze samotného spalování biomasy v MTZ jsou $v$ tab. 1. Pro porovnání připojujeme limitní hodnoty rizikových prvků obsažených $\vee$ popelu ze spalování biomasy, které dle prílohy č. 1 vyhlášky č. 474/2000 Sb., Ize použít jako hnojivo na zemědělské půdy nebo do kompostu (od 1. října 2021 byly limity navýšeny, viz Přiloha č. 1 k vyhlášce č. 312/2021 Sb.). Použití popela z biomasy při kultivaci zemědělské pưdy se řídí zákonem č. 156/1998 Sb.1, o hnojivech, ve znění pozdějších předpisů, což znamená, že popel podléhá registraci jako hnojivo a musí splňovat požadavky Př́lohy č. 1 k vyhlášce č. 474/2000 Sb., respektive č. 312/2021 Sb., o stanovení požadavků na hnojiva, ve znění pozdějších předpisů.

Obsahy rizikových prvků uvádí práce výzkumníků Vysoké školy báňské Technické univerzity Ostrava [9], která popisuje výsledky analýz popelů vzniklých spalováním v MTZ tři druhů hnědého uhlí běžně využívaných $\vee$ České republice. Dokument uvádí, že převážná většina sledovaných prvků (Al, Si, K, $\mathrm{Ca}, \mathrm{Ti}, \mathrm{V}, \mathrm{Cr}, \mathrm{Mn}$, Fe, Co, Ni, Cu, Zn, As, Rb) se hromadila v ložovém popelu; Se a Pb byly dominantně zastoupeny v úletovém popelu, zatímco v plynných emisích se nacházely $\mathrm{S}, \mathrm{Cl}, \mathrm{Br}$ a Hg. Při porovnání s distribucí prvků vzniklých spalováním uhlí ve velkých průmyslových systémech byl nalezen rozdíl hlavně u As a Zn, který pravděpodobně souvisel s relativně nízkými teplotami v topeništi i teplotami odcházejících spalin. Konkrétní výsledky jsou uvedeny v tab. 2.

Polská studie [10] porovnala spalování černého uhlí v MTZ s teplárnami. Ve vzorcích z MTZ bylo významně více stopových prvků (Cd, Tl, Pb, As, Ba a Ni) než ve vzorcích teplárenských ložových popelů. Průměrný obsah těchto prvků byl 1,5 až 3,5krát vyšší než ve vzorcích teplárenských ložových popelů. Obsahy stopových prvků v popelech černého uhlí spáleného v MTZ jsou pro srovnání rovněž uvedeny $v$ tab. 2. 
Tab. 2. Obsahy prvkư v ložových popelech hnědého a černého uhlíz MTZ [9, 10]

Tab. 2. Contents of elements in bed ashes of brown and black coal from small heat sources $[9,10]$

\begin{tabular}{|c|c|c|c|c|c|c|c|}
\hline \multirow{2}{*}{ Prvek } & \multicolumn{7}{|c|}{ Výsledky analýz jednotlivých druhů hnědého (HU) a černého uhlí (ČU) [mg/kg sušiny] } \\
\hline & HU I & HU II & HU III & ČU I & ČU II & ČU III & ČU IV \\
\hline $\mathrm{Cd}$ & nestanoveno & nestanoveno & nestanoveno & 0,7 & 1,3 & 1,5 & 1,7 \\
\hline $\mathrm{Cl}$ & 160,9 & 378,8 & 437,0 & nestanoveno & nestanoveno & nestanoveno & nestanoveno \\
\hline V & 242,3 & 614,8 & 370,2 & nestanoveno & nestanoveno & nestanoveno & nestanoveno \\
\hline $\mathrm{Cr}$ & 110,2 & 292,4 & 175,2 & 33 & 87 & 101 & 112 \\
\hline $\mathrm{Mn}$ & 191,3 & 158,4 & 256,4 & nestanoveno & nestanoveno & nestanoveno & nestanoveno \\
\hline $\mathrm{Fe}$ & 101,0 & 53,0 & 73,2 & 4,9 & 2,8 & 3,1 & 3,0 \\
\hline Co & 70,0 & 57,7 & 96,0 & nestanoveno & nestanoveno & nestanoveno & nestanoveno \\
\hline $\mathrm{Ni}$ & 103,0 & 93,7 & 120,2 & 20,0 & 99,0 & 135,0 & 143,0 \\
\hline $\mathrm{Cu}$ & 42,2 & 309,2 & 158,9 & 77,0 & 96,0 & 117,0 & 98,0 \\
\hline $\mathrm{Zn}$ & 76,5 & 51,9 & 160,5 & 645,0 & 660,0 & 672,0 & 644,0 \\
\hline As & 282,4 & 352,2 & 1582,0 & 12,0 & 18,0 & 26,0 & 24,0 \\
\hline Se & 0,1 & 0,1 & 0,1 & nestanoveno & nestanoveno & nestanoveno & nestanoveno \\
\hline $\mathrm{Ba}$ & nestanoveno & nestanoveno & nestanoveno & 750,0 & 1125,0 & 1260,0 & 1168,0 \\
\hline $\mathrm{Br}$ & 10,5 & 13,9 & 13,0 & nestanoveno & nestanoveno & nestanoveno & nestanoveno \\
\hline $\mathrm{Rb}$ & 34,8 & 25,0 & 39,3 & nestanoveno & nestanoveno & nestanoveno & nestanoveno \\
\hline $\mathrm{Hg}$ & 0,030 & 0,035 & 0,061 & nestanoveno & nestanoveno & nestanoveno & nestanoveno \\
\hline $\mathrm{Pb}$ & 7,5 & 16,5 & 27,4 & 48,0 & 66,0 & 78,0 & 99,0 \\
\hline
\end{tabular}

Zdroj: $[9,10]$

Tab. 3. Výsledky analýz výluhü ložových popelů ze spalování hnědého uhlív MTZ

Tab. 3. Results of analyzes of leachate ash extracts from brown coal combustion in small heat resources

\begin{tabular}{|c|c|c|c|c|}
\hline \multirow{2}{*}{ Ukazatel } & \multicolumn{3}{|c|}{ Výsledky analýz [mg/l] } & \multirow{2}{*}{ Vyhláška č. 273/2021 Sb. třída Ila } \\
\hline & HU I & HU II & HU III & \\
\hline $\mathrm{pH}$ & 6,1 & 5,8 & 5,9 & $\geq 6$ \\
\hline konduktivita & 1,0 & 2,8 & 2,9 & \\
\hline chloridy & $<3,5$ & $<3,5$ & $<3,5$ & 1500 \\
\hline sírany & 630,4 & 2243,8 & 2202,7 & 3000 \\
\hline Co & $<0,1$ & $<0,1$ & $<0,1$ & - \\
\hline $\mathrm{Cr}$ & $<0,1$ & $<0,1$ & $<0,1$ & 7 \\
\hline $\mathrm{Cu}$ & $<0,2$ & $<0,2$ & $<0,2$ & 10 \\
\hline $\mathrm{Fe}$ & $<0,2$ & $<0,2$ & $<0,2$ & - \\
\hline $\mathrm{Mn}$ & 0,2 & 1,0 & 0,8 & - \\
\hline $\mathrm{Ni}$ & $<0,1$ & 0,1 & 0,1 & 4 \\
\hline $\mathrm{Zn}$ & $<0,1$ & 0,1 & 0,1 & 20 \\
\hline
\end{tabular}

Zdroj: [9] 
Tab. 4. Produkce popelů a odhad indikativni produkce směsného odpadu v obcích DSO

Tab. 4. Ash production and indicative output estimation of mixed waste in DSO municipalities

\begin{tabular}{|c|c|c|c|c|c|}
\hline \multirow{2}{*}{ Obec } & Popel z uhlí & SKOmin & SKOmax & SKOmin & SKOmax \\
\hline & [kg/ob/rok] & [kg/ob/rok] & [kg/ob/rok] & [t/rok $]$ & [t/rok] \\
\hline Břežany & 60,6 & 131,6 & 197,1 & 25,92 & 38,82 \\
\hline Hejná & 56,1 & 127,5 & 193,4 & 20,78 & 31,52 \\
\hline Horažd’ovice & 29,9 & 93,6 & 156,1 & 499,53 & 832,89 \\
\hline Hradešice & 78,3 & 150,4 & 215,7 & 63,63 & 91,23 \\
\hline Chanovice & 40,0 & 109,4 & 175,1 & 79,41 & 127,08 \\
\hline Kejnice & 69,5 & 146,5 & 214,3 & 15,67 & 22,93 \\
\hline Kovčín & 73,5 & 153,3 & 222,3 & 12,88 & 18,67 \\
\hline Kvášňovice & 75,4 & 152,5 & 220,1 & 17,54 & 25,31 \\
\hline Malý Bor & 78,4 & 148,5 & 212,9 & 73,05 & 104,73 \\
\hline Maňovice & 33,2 & 114,0 & 187,4 & 5,36 & 8,81 \\
\hline Myslív & 79,9 & 156,3 & 223,4 & 64,57 & 92,26 \\
\hline Nalžovské Hory & 67,7 & 145,3 & 213,6 & 170,17 & 250,12 \\
\hline Olšany & 71,0 & 139,5 & 203,4 & 28,88 & 42,11 \\
\hline Pačejov & 63,3 & 131,7 & 195,7 & 99,28 & 147,58 \\
\hline Slatina & 53,0 & 125,4 & 192,1 & 13,05 & 19,98 \\
\hline Velké Hydčice & 31,6 & 95,8 & 158,5 & 24,23 & 40,10 \\
\hline Velký Bor & 37,5 & 105,5 & 170,4 & 57,17 & 92,36 \\
\hline
\end{tabular}

Zdroj: Vlastní výpočet Dobrovolného svazku obcí Horaždovicko

Zvýšený obsah síranů ve výluzích byl pravděpodobně důvodem i vyšší hodnoty konduktivity vodných výluhů ložových popelů a splnil pouze třídu lla Přilohy č. 10 k vyhlášce č. 273/2021 Sb., o podrobnostech nakládání s odpady.

Zákon č. 201/2012 Sb., o ochraně ovzduší, ve znění pozdějších predpisů, v odstavci 6 § 16 uvádí, že: „Odpad podle jiného právního předpisu [zákona o odpadech] s výjimkou odpadu uvedeného v prováděcím právním předpisu, může být tepelně zpracován jen ve stacionárním zdroji, ve kterém je tepelné zpracování odpadu povoleno podle § 11 odst. 2 písm. d). Tepelné zpracování odpadu je možné pouze pod dohledem osoby autorizované podle $\S 32$ odst. 1 písm. c).“ V § 17 odstavci 1 je také uvedeno, že: „Provozovatel stacionárního zdroje je povinen spalovat ve stacionárním zdroji pouze paliva, která splňují požadavky na kvalitu paliv stanovené prováděcím právním predpisem, a jsou určena výrobcem stacionárního zdroje nebo paliva uvedená v povolení provozu." To tedy znamená, že v MTZ je spalování odpadů nelegální.

Ke zjištění, že domácnost takto nezákonně nakládá s odpadem, Ize dojít dvěma způsoby. Prvním, poněkud obtížně prokazatelným, je sledování barvy a intenzity kouře z MTZ, druhým, presnějším, tzv. metoda SEMAFOR [11].

Je to metoda, která byla vytvořena za účelem posouzení popelů z pohledu spalování odpadů v MTZ. Cílem této metody je po vyhodnocení výsledků označit popel jako červený (prokázáno spalování kontaminovaného paliva), oranžový (spalování kontaminovaného paliva nelze prokázat ani vyloučit), nebo zelený (neprokázáno spalování kontaminovaného paliva). Součástí metodiky [11] je i katalog popelů.
Analýzy popelů vzniklých spalováním uhlí společně s komunálním odpadem přináší článek Kicinské [12]. Studie prezentuje výsledky analýzy popílku, který je výsledkem spalování tuhých paliv smíchaných s komunálním odpadem, a hodnotí environmentální a zdravotní riziko spojené s infiltrací vybraných kovů do životního prostředí. Fázové složení naznačuje, že materiál je extrémně smíšený a různorodý. Nízkoteplotní složky byly smíchány s látkami vytvářenými při vysokých teplotách. Variabilní složení odpadu z různých domácích pecí s vysokým obsahem amorfní fáze (jež se ve vodě rozpouští snadněji než její krystalické ekvivalenty) může být škodlivé pro lidské zdraví i životní prostředí.

Jako dominantní prvky byly zjištěny křemičitany a hlinitokřemičitany - křemen, živec a plagioklas (albit). Hojně se zde vyskytovaly také hliněné minerály (kaolinit a mullit), uhličitany (kalcit), oxidy/oxidhydroxidy železa a síranové minerály (sádra a anhydrit). Hlavními složkami částic byly oxidy Si, Al, Ca a Fe (85,5\%), zatímco oxidy S, Mg, Na, Ka Ti predstavovaly $12,6 \%$ z celkového obsahu.

Kodex hodnocení rizika navrhl:

- nízké riziko pro As, $\mathrm{Co}, \mathrm{Cr}, \mathrm{Ni}$

- střední riziko pro $\mathrm{Cd}$, Cu a Pb

- vysoké riziko pro $\mathrm{Zn}$ 


\section{ANALÝZA SLOŽENÍ ODPADU゚}

VúV TGM v rámci řešení projektu CZ.07.1.02/0.0/0.0/16_040/0000379 „Odpady a předcházení jejich vzniku - praktické postupy a činnosti při realizaci závazkủ krajského Plánu odpadového hospodárství hlavního města Prahy" [13] a dalších zakázek provádí rozbory směsného komunálního odpadu v sídlištní, venkovské i centrální zástavbě hlavního města Prahy. Díky centrálnímu vytápění a plynofikaci se popel ve směsném komunálním odpadu téměř nevyskytuje. Dle Čsú [14] se procento domácností používajících pevná paliva v jednotlivých krajích pohybuje v rozmezí od 0,4% (hlavní město Praha) až pro 22,6 \% (Středočeský kraj).

Pro občany, respektive domácnosti $v$ malých obcích, vlastnící MTZ je popel zásadní složkou obsahu směsného komunálního odpadu (SKO). Při předběžném monitoringu produkce popelů v pilotní oblasti Horaždovicko bylo Ing. Vachuškou zjištěno, že v obcích Dobrovolného svazku obcí (DSO) Horaždovicko vzniká 520 tun popelů ročně. Jedná se prevážně o popel ze spalování uhlí, přičemž jeden občan ročně vyprodukuje v průměru 46 kg popela. $\checkmark$ jednotlivých obcích DSO se roční produkce popelů pohybuje $v$ rozmezí 30-80 kg na obyvatele (viz tab. 4).

Takovéto množství představuje i vzhledem k avizovaným vzrůstajícím cenám za uložení odpadu na skládky (podle nového zákona o odpadech Č. 541/2020 Sb., [15] bude cena za tunu využitelného odpadu postupně navyšována až na částku 1850 Kč v roce 2030) velmi citelným nákladem jak pro obce, tak následně pro samotného občana. Současně takové množství ztíži plnění recyklačních povinností, ke kterým se ČR zavázala (do roku 2035 dosáhnout 65 \% opětovně využitého nebo recyklovaného komunálního odpadu z celkové hmotnosti komunálních odpadů vyprodukovaných na území ČR [15]).
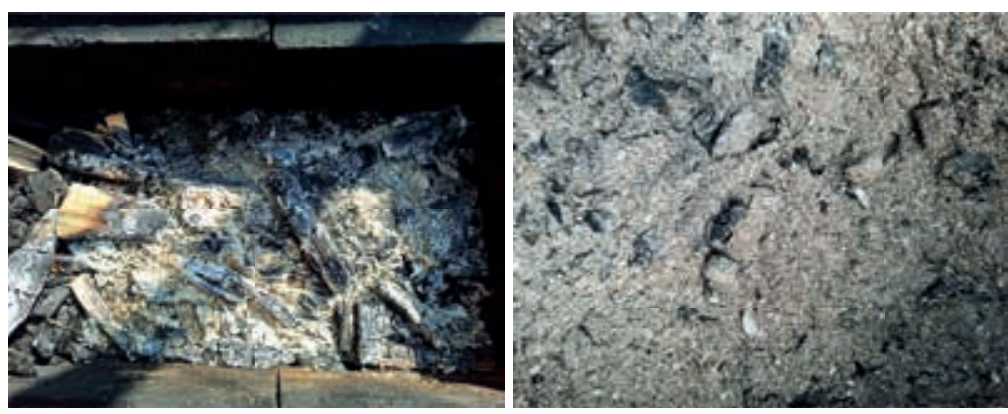

Obr. 1. Druhy popelů z MTZ (z biomasy vlevo a uhelný vpravo)

Fig. 1. Types of ashes from small heat sources (from biomass on the left and coal on the right)

\section{ZPU゚SOB ÚPRAVY A ZPRACOVÁNÍ}

V současné době je popel z MTZ odkládán do popelnic a s dalším směsným komunálním odpadem odstraňován ukládáním na skládky, prípadně spalován ve spalovnách. Pokud je soustřed’ován odděleně, má výrazně jiné vlastnosti než směsný komunální odpad. Např́klad nedosahuje výhřevnosti 6,5 MJ/kg v sušině a je biologicky stabilní. Od 1. ledna 2024 bude možné separovaný popel z MTZ zařadit jako poddruh směsného komunálního odpadu s katalogovým označením 20030101 - Odděleně soustřed’ovaný popel z domácností. Tento poddruh odpadu dle Př́lohy č. 52 k vyhlášce č. 273/2021 Sb., o nakládání s odpady patří mezi technologické odpady, a je proto zahrnut do dílčího poplatku za ukládání technologických odpadi̊ na skládku. Sazba za tunu vytříděného skládkovaného popela činí 45 Kč. Popel Ize při odděleném sběru v obcích kumulovat již nyní na vybraném místě v regionu a dalším zpracováním z něj vyrobit posypové kamenivo pro zimní údržbu komunikací nebo podsypový a zásypový materiál liniových staveb. Obec tak splní recyklační povinnosti a ušetří prírodní neobnovitelné zdroje.

Posypové/umělé kamenivo je možné vyrobit speciální technologií z popela, příměsí, pojiv a prísad, které jsou dostupné. Výroba posypového/umělého kameniva již byla laboratorně a poloprovozně ověrena. $V$ současné době je možné zavedení tohoto způsobu recyklace popela z MTZ realizováno první etapou, tedy podáním žádosti o podporu projektu „Potenciál materiálového využití popela v rámci cirkulární ekonomiky obci" pro 5. veřejnou soutěž programu Prostředí pro život vyhlášeného Technologickou agenturou ČR (TA ČR). Dalšími etapami recyklace popela z MTZ bude podpora zavádění a organizace jeho odděleného sběru v obcích a pořizení technologie na jeho zpracování.

Podle poznatků Ing. Vachušky je výhodou posypového/umělého kameniva z popela MTZ možnost řizení jeho vybraných mechanicko-fyzikálních vlastností a životnosti. To znamená, že při zpracování popela z MTZ je možné předem nastavit vlastnosti posypového/umělého kameniva, jako napríklad pevnost, nasákavost a další, pro environmentálně bezpečné použití důležité vlastnosti.

\section{ZÁVĚR}

Technologický odpad, mezi který patří například škváry, strusky, shrabky z česlí i odděleně soustřed’ovaný popel z domácností, je zařazen do skupiny odpadů, jež se Ministerstvo životního prostředí snaží odstranit na skládky. Chce tímto způsobem vyřešit problém nadměrného využívání těchto minimálně upravených odpadů na povrchu terénu, a zabránit tak možné kontaminaci životního prostředí. Výše uvedený způsob třídění a recyklace popelů z MTZ zajistí environmentálně bezpečný materiál s širokým využitím a současně přispěje ke splnění závazků obcí v rámci zásad oběhového hospodářství.

Tab. 5. Produkce odpadĩ v obcích DSO Horaždovicko v letech 2016-2019 [kg/ob]

Tab. 5. Waste production in DSO Horaždovicko municipalities in the years 2016 -2019 [kg/citizen]

\begin{tabular}{|c|c|c|c|c|c|c|c|}
\hline \multirow{2}{*}{ Rok } & Směsný odpad & Papír & Plasty & Sklo & Bioodpad & Zbytek & Celkem \\
\hline & {$[\mathrm{kg} / \mathrm{ob}]$} & {$[\mathrm{kg} / \mathrm{ob}]$} & {$[\mathrm{kg} / \mathrm{ob}]$} & {$[\mathrm{kg} / \mathrm{ob}]$} & {$[\mathrm{kg} / \mathrm{ob}]$} & {$[\mathrm{kg} / \mathrm{ob}]$} & {$[\mathrm{kg} / \mathrm{ob}]$} \\
\hline 2016 & 187,1 & 12,3 & 10,6 & 14,3 & 100,7 & 100,0 & 425,0 \\
\hline 2017 & 197,4 & 10,7 & 9,3 & 13,9 & 96,9 & 96,0 & 424,2 \\
\hline 2018 & 207,8 & 14,7 & 10,9 & 14,1 & 83,7 & 114,6 & 445,6 \\
\hline 2019 & 204,0 & 19,1 & 14,2 & 15,1 & 95,3 & 101,9 & 449,6 \\
\hline
\end{tabular}

Zdroj: Vlastní výpočet Dobrovolného svazku obcí Horaždovicko 


\section{Poděkování}

Př́spěvek byl podpořen z institucionálních prostředků na rozvoj výzkumné organizace - VÚv TGM v rámci interního grantu č. U4802/2021.

\section{Poznámky}

1. Od 1. řijna 2021 vstoupil v platnost zákon č. 299/2021 Sb., kterým se mění zákon č. 156/1998 Sb., o hnojivech, pomocných půdních látkách, pomocných rostlinných prípravcích a substrátech a o agrochemickém zkoušení zemědělských půd (zákon o hnojivech), ve znění pozdějších předpisů, a další související zákony.

\section{Literatura}

[1] MAYER, A., HAAS, W., WIEDENHOFER, D., KRAUSMANN, F., NUSS, P., BLENGINI, G. A. Measuring Progress towards a Circular Economy: A Monitoring Framework for Economy-Wide Material Loop Closing in the EU28. Journal of Industrial Ecology [on-line]. 2019, 23(1), s. 62-76. ISSN 1088-1980, 1530-9290. Dostupné z: doi: 10.1111/jiec.12809

[2] The Circular Economy in Cities and Regions: Synthesis Report |OECD iLibrary [on-line]. [vid. 23. srpen 2021]. Dostupné z: https://www.oecd-ilibrary.org/sites/10ac6ae4-en/../cfe-2020-811-en/index.html

[3] SARKAR, D. K. Thermal Power Plant: Design and Operation. 1. Amsterdam: Elsevier, 2015. ISBN 978-0-12-801575-9.

[4] 70+ Uses for Wood Ash. Practical Self Reliance [on-line]. 27. prosinec 2018 [vid. 27. srpen 2021]. Dostupné z: https://practicalselfreliance.com/wood-ash-uses/

[5] Holzpellets DINplus - Pellets online vergleichen, günstig bestellen \& sparen [on-line]. [vid. 24. srpen 2021]. Dostupné z: https://www.meine-holzpellets.de/

[6] Entsorgung der Asche bei Pelletheizungen und Pelletöfen [on-line]. [vid. 27. srpen 2021]. Dostupné z: https://www.wohlundwarm.de/glossar/entsorgung-der-asche

[7] Merkblatt_Holzasche def web.pdf [on-line]. [vid. 27. srpen 2021]. Dostupné z: https://www.abfall. ch/pages/info/pdf/Merkblatt_Holzasche_def_web.pdf

[8] HAVEL, M. Odpadové hospodářství malých obcí - príručka pro obce, aktualizace 2020 [on-line]. B. m. ARNIKA, 2020. Dostupné z: https://arnika.org/odpadove-hospodarstvi-malych-obci-aktualizace-2020

[9] RITZ, M., JUREČKA, P., KLIKA, Z., CHALUPA, V., MOHYLA, D., ŠTEFANIDESOVÁ, V. Produkty spalování tuhých paliv v malých domácích topeništích. I. Spalování hnědého uhlí. Sborníkvědeckých pracíVysoké školy báňské - Technické univerzity Ostrava. R̈ada hornicko-geologická. 2005, č. 1, s. 14. ISSN 0474-8476. Dostupné z: http://gse.vsb.cz/2005/LI-2005-1-55-68.pdf

[10] SMOŁKA-DANIELOWSKA, D., KADZIOŁKA-GAWEL, M., KRZYKAWSKI, T. Chemical and Mineral Composition of Furnace Slags Produced in the Combustion Process of Hard Coal. International Journal of Environmental Science and Technology [on-line]. 2019, 16(10), s. 5387-5396. ISSN 1735-2630. Dostupné z: doi: 10.1007/s13762-018-2122-z

[11] Pokud někdo doma spaluje odpad, existuje metoda, jak mu to prokázat? TZB-info [on-line]. [vid. 27. srpen 20211. Dostupné z: https://vytapeni.tzb-info.cz/vytapime-pevnymi-palivy/18367-pokudnekdo-doma-spaluje-odpad-existuje-metoda-jak-mu-to-prokazat

[12] KICIŃSKA, A. Chemical and Mineral Composition of Fly Ashes from Home Furnaces, and Health and Environmental Risk Related to their Presence in the Environment. Chemosphere [on-line]. 2019, 215, s. 574-585. ISSN 0045-6535. Dostupné z: doi: 10.1016/j.chemosphere.2018.10.061

[13] VOLOŠINOVÁ, D., KOŘíNEK, R., MAKOVCOVÁ, M. Monitoring odpadové obslužnosti pro tříděné složky komunálního odpadu na území hlavního města Prahy. Vodohospodárskétechnicko-ekonomické informace. 2019, 61(6), s. 40-46. ISSN 0322-8916, 1805-6555.

[14] Energo 2015. Energo 2015 [on-line]. [vid. 15. červen 2021]. Dostupné z: https://www.czso.cz/csu/ czso/energo-2015

[15] INFO@AION.CZ, A.C.-. 541/2020 Sb., Zákon o odpadech. Zákony pro lidi [on-line]. [vid. 14. červen 2021]. Dostupné z: https://www.zakonyprolidi.cz/cs/2020-541

\section{Autoři}

Ing. Dagmar Vološinová1

$凶$ dagmar.volosinova@vuv.cz

ORCID: 0000-0003-1195-7046

Ing. Elžbieta Čejka ${ }^{1}$

凶elzbieta.cejka@vuv.cz

Ing. Robert Kořínek ${ }^{1}$

凶robert.korinek@vuv.cz

ORCID: 0000-0001-5849-5606

Ing. Václav Vachuška²

凶vachuska@ekostat.cz

Ing. Aleš Vachuška²

凶aless.vachuska@seznam.cz

Ing. Jan Vachuška

凶jan.vachuska@mineral.eu

'Výzkumný ústav vodohospodářský T. G. Masaryka, Praha

${ }^{2}$ EKOSTAT a.s.

Příspěvek prošel lektorským řízením.

DOI: 10.46555/VTEI.2021.09.002

\section{ASH MANAGEMENT IN THE CIRCULAR ECONOMY OF MUNICIPALITIES}

\section{VOLOSINOVA, D.'; VACHUSKA, V.'; CEJKA, E. '; KORINEK, R. ${ }^{2}$; VACHUSKA, A. ${ }^{2}$; VACHUSKA, J. ${ }^{2}$}

${ }^{1}$ T. G. Masaryk Water Research Institute Prague ${ }^{2}$ EKOSTAT JSC

Keywords: ash - waste - municipal waste waste management - circular economy

Ash from small heat sources is produced by burning solid fuels such as wood and coal. Based on a survey conducted by the article authors, ash from small heat sources can be considered the most significant waste stream in smaller municipalities in the Czech Republic. This material has considerable potential for reducing waste production, landfilling and consumption of primary raw materials. The presented possibilities of using this potential will comply with the hierarchy of waste management, but also with the strategy of sustainable development of many municipalities. This article uses the analysis of the material composition of mixed municipal waste from the voluntary union of municipalities Horaždovicko to demonstrate a possible way of fundamental assistance, especially to small municipalities, in an environmentally friendly way, to fulfil their obligations arising from the new waste legislation. 